\title{
PENYELESAIAN PERSAMAAN DIFERENSIAL TUNDA LINIER ORDE 1 DENGAN METODE KARAKTERISTIK
}

\author{
FEBBY RAHMI ALFIONITA, ZULAKMAL \\ Program Studi Matematika, \\ Fakultas Matematika dan Ilmu Pengetahuan Alam, Universitas Andalas, \\ Kampus UNAND Limau Manis Padang, Indonesia, \\ email :febbyrahmi@gmail.com
}

\begin{abstract}
Abstrak. Pada paper ini akan dikaji tentang bagaimana cara memperoleh solusi permasamaan diferensial tunda linier orde satu. Adapun metode yang digunakan pada penulisan ini adalah metode karakteristik. Hasil menunjukkan bagaimana pertumbuhan konstanta $\alpha$ dan konstanta delay $\delta$. Selain itu, diperoleh tak hingga banyaknya himpunan dari solusi karakteristik untuk beberapa kasus.
\end{abstract}

Kata Kunci: Persamaan diferensial tunda, Teorema Picard

\section{Pendahuluan}

Persamaan diferensial adalah suatu persamaan yang memuat turunan-turunan dari suatu fungsi yang tidak diketahui dengan satu atau lebih variabel. Secara umum ada dua macam persamaan diferensial, yaitu persamaan diferensial biasa dan persamaan diferensial parsial. Persamaan diferensial biasa merupakan persamaan diferensial yang hanya mempunyai satu peubah bebas dan memuat turunan biasa, sedangkan persamaan diferensial parsial merupakan persamaan diferensial yang mempunyai lebih dari satu peubah bebas dan memuat turunan-turunan parsial.

Suatu persamaan diferensial disebut persamaan diferensial tunda jika persamaan tersebut tidak hanya bergantung kepada waktu sekarang tetapi juga bergantung kepada waktu sebelumnya. Persamaan diferensial tunda awalnya diperkenalkan pada abad ke-18 oleh Laplace dan Condorcet. Waktu tunda penting dalam pemodelan masalah nyata karena keputusan biasanya dibuat berdasarkan informasi pada waktu sebelumnya. Bentuk umum persamaan diferensial tunda orde satu dapat ditulis sebagai berikut:

$$
y^{\prime}(t)=f(t, y(t), y(t-q))
$$

untuk suatu $q>0$, dimana $y(t-q)$ bergantung pada waktu $t-q$ di waktu lampau, dan pada nilai $y(t)$ pada waktu sekarang [5]. Dalam makalah ini akan dikaji bagaimana bentuk solusi dari persamaan diferensial tunda linier orde satu yang berbentuk

$$
\begin{aligned}
y^{\prime}(t) & =\alpha y(t-\delta), \text { pada }[0, b], b>0 \\
y(t) & =\phi(t), \text { pada }[-\delta, 0],
\end{aligned}
$$


dengan $\delta>0, \alpha \in R$, dengan menggunakan metode karakteristik. Dalam persamaan (1.2), fungsi $\phi(t)$ disebut sebagai pre-function dan interval $[-\delta, 0]$ disebut pre-interval [4].

\section{Penyelesaian Persamaan Diferensial Tunda Linier Orde 1 dengan menggunakan Metode karatketristik}

Perhatikan kembali persamaan (1.2). Metode karakteristik merupakan suatu cara untuk mendapatkan solusi dari pesamaan diferensial tunda (1.2). Penggunaan metode tersebut dapat dijelaskan sebagai berikut. Misalkan

$$
y(t)=C e^{r t},
$$

dimana $C$ merupakan kontanta sebarang dan $r$ adalah parameter. Dengan mensubstitusikan persamaan (2.1) ke dalam persamaan (1.2) diperoleh persamaan nonlinier berikut:

$$
r e^{r \delta}-\alpha=0 .
$$

Persamaan (2.2) disebut sebagai persamaan karakteristik untuk persamaan (1.2).

Misalkan $\delta$ adalah suatu bilangan positif tetap dan definisikan $f(r)$ sebagai

$$
f(r)=r e^{r \delta}-\alpha .
$$

Agar (2.1) merupakan solusi untuk (1.2), maka $r$ haruslah merupakan akar dari persamaan (2.3). Dari persamaan (2.2), jika $\alpha=0$ maka diperoleh $r=0$, sehingga persamaan (2.3) hanya memiliki satu akar, sehingga solusi untuk persamaan (1.2) adalah $y(t)=C$.

Gambar 1 memperlihatkan grafik dari $f(r)$ untuk $\delta=2$ dan berbagai variasi dari parameter $\alpha$, dengan $\alpha \neq 0$.

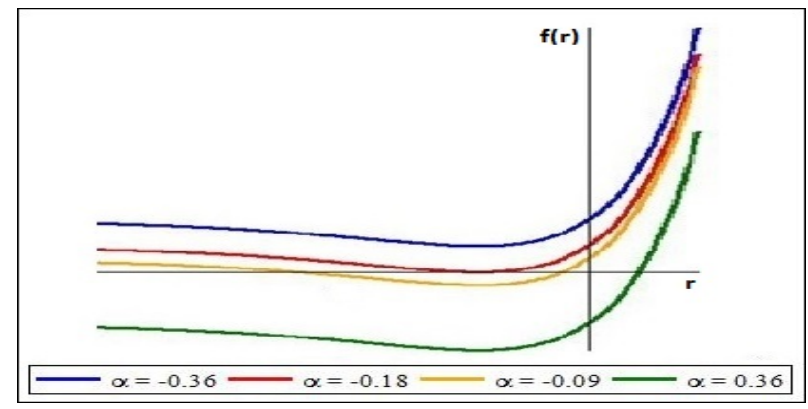

Gambar 1. Grafik $f(r)$

Gambar 1 memperlihatkan bahwa solusi dari persamaan (1.2) bergantung kepada empat kasus, dimana terdapat kasus yang memuat solusi riil, tetapi dalam setiap kasus memuat tak berhingga banyaknya solusi kompleks yang eksistensinya dijamin oleh Teorema Picard. Misalkan bilangan kompleks $z=p+i q, \quad p, q \in R$ merupakan akar dari persamaan (2.3), sedemikan sehingga $z e^{z \delta}-\alpha=0$. 
Sehingga diperoleh

$$
\begin{aligned}
p \cos (q \delta)-q \sin (q \delta) & =\alpha e^{-p \delta} \\
p \sin (q \delta)+q \cos (q \delta) & =0 . \\
p & =-q \cot (q \delta) .
\end{aligned}
$$

Jika $q \rightarrow 0$, maka $p \rightarrow-\frac{1}{\delta}$. Dengan mensubstitusikan $(p, q)=\left(-\frac{1}{\delta}, 0\right)$ ke dalam persamaan (2.4) diperoleh $\alpha=-\frac{1}{\delta e}$. Dengan demikian, jika $\alpha=-\frac{1}{\delta e}$ maka diperoleh satu akar riil dari $f(r)$, yaitu $r=-\frac{1}{\delta}$.

Selanjutnya, misalkan $q \neq 0$. Substitusikan $p$ pada persamaan (2.6) ke dalam persamaan (2.4), diperoleh

$$
q=-\alpha e^{q \delta \cot (q \delta)} \sin (q \delta)
$$

Dari $\alpha<0$ diperoleh dua kemungkinan lain, yaitu $\alpha<-\frac{1}{\delta e}<0$ dan $-\frac{1}{\delta e}<$ $\alpha<0$. Perhatikan kasus $\alpha<-\frac{1}{\delta e}<0$. Misalkan $X=q \delta$, maka persamaan (2.7) dapat ditulis sebagai berikut

$$
X=-\alpha \delta \sin (X) e^{X \cot (X)} .
$$

Penyelesaian persamaan (2.8) diperoleh dengan mendapatkan irisan garis $Y=X$ dan keluarga kurva satu parameter

$$
Y=-\alpha \delta \sin (X) e^{X \cot (X)},
$$

yang grafiknya diperlihatkan oleh Gambar 2 .

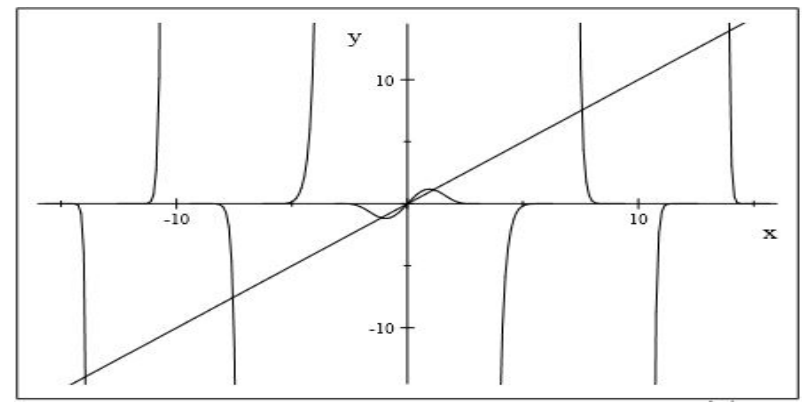

Gambar 2. Grafik $Y=X$ dan $Y=\alpha \delta \sin (X) e^{X \cot (X)}$

Gambar 2 memperlihatkan bahwa persamaan (2.8) mempunyai tak hingga banyaknya solusi, nyatakan solusi tersebut dengan $X_{k}, k=1,2,3, \cdots$, dan misalkan $q_{k}=\frac{X_{k}}{\delta}, k=1,2,3, \cdots$. Terkait dengan $q_{k}$ ini, diperoleh juga $p_{k}$ sedemikian sehingga $z_{k}=p_{k}+i q_{k}, k=1,2,3, \cdots$. Kasus ini memperlihatkan bahwa tidak ada akar riil dari $f(r)$. Oleh karena itu dari (2.1) diperoleh

$$
y_{k}(t)=e^{p_{k} t}\left(C_{1 k} \cos \left(q_{k} t\right)+C_{2 k} \sin \left(q_{k} t\right)\right),
$$


dimana $C_{2 k}=i C_{1 k}$ adalah konstanta sebarang. Selanjutnya, karena persamaan (1.2) adalah linier dan homogen, maka solusinya adalah

$$
y(t)=\sum_{k=1}^{\infty} e^{p_{k} t}\left(C_{1 k} \cos \left(q_{k} t\right)+C_{2 k} \sin \left(q_{k} t\right)\right) .
$$

Untuk kasus $\alpha=-\frac{1}{\delta e}$, maka solusi dari (1.2) adalah

$$
y(t)=C_{0} e^{-\frac{1}{\delta} t}+\sum_{k=1}^{\infty} e^{p_{k} t}\left(C_{1 k} \cos \left(q_{k} t\right)+C_{2 k} \sin \left(q_{k} t\right)\right) .
$$

Selanjutnya, perhatikan kasus $-\frac{1}{\delta e}<\alpha<0$. Untuk menentukan nilai $r$ ini dapat digunakan hampiran numerik menggunakan metode Newton, yaitu untuk sebarang bilangan bulat positif $k$, definisikan

$$
s_{k+1}=s_{k}-\frac{f\left(s_{k}\right)}{f^{\prime}\left(s_{k}\right)}
$$

sedemikian sehingga $r=\lim _{k \rightarrow \infty} s_{k}$.

Sebagai ilustrasi, misalkan $\alpha=-\frac{1}{2 \delta e}$, jika $\delta=2$ maka $\alpha=-\frac{1}{4 e}$. Jika $r_{0}$ merupakan akar yang lebih besar dari $-\frac{1}{\delta}$, yaitu $r_{0}>-\frac{1}{\delta}$, mulai dengan $s_{0}=-\frac{1}{2 \delta}$. Dengan menggunakan (2.13) diperoleh $r_{0}=\lim _{k \rightarrow \infty} s_{k}=-0,116$.

Jika $r_{1}$ merupakan akar yang lebih kecil dari $-\frac{1}{\delta}$, yaitu $r_{1}<-\frac{1}{\delta}$, mulai dengan $s_{0}=-\frac{2}{\delta}$. Dengan menggunakan (2.13) diperoleh $r_{1}=\lim _{k \rightarrow \infty} s_{k}=-1,339$.

Diperoleh bahwa terdapat dua akar riil dari $f(r)$ untuk kasus $-\frac{1}{\delta e}<\alpha<0$. Dengan demikian solusi dari persamaan (1.2) adalah

$$
y(t)=C_{1} e^{r_{0} t}+C_{2} e^{r_{1} t}+\sum_{k=1}^{\infty} e^{p_{k} t}\left(C_{1 k} \cos \left(q_{k} t\right)+C_{2 k} \sin \left(q_{k} t\right)\right) .
$$

Selanjutnya misalkan $\alpha>0$. Sebagai ilustrasi, misalkan $\alpha=\frac{1}{\delta e}$ dengan $\delta=2$. Dengan menggunakan $s_{0}=1$ diperoleh $r=\lim _{k \rightarrow \infty} s_{k}=0,1392$.

Maka diperoleh bahwa terdapat satu akar riil positif dari $f(r)$ untuk kasus $\alpha>0$. Jadi, solusi bagi persamaan (1.2) adalah

$$
y(t)=C_{3} e^{r t}+\sum_{k=1}^{\infty} e^{p_{k} t}\left(C_{1 k} \cos \left(q_{k} t\right)+C_{2 k} \sin \left(q_{k} t\right)\right) .
$$

Dari penjelasan di atas, maka Teorema berikut ini telah terbukti.

Teorema 2.1. [2] Misalkan $\delta, \alpha \in R$ dengan $\delta>0, \alpha \neq 0$ dan $p_{k}+i q_{k}, k=$ $1,2,3, \cdots$ merupakan akar-akar kompleks dari persamaan (2.2) yang diperoleh dari persamaan (2.4) dan (2.5). Maka untuk sebarang konstanta $C_{k}$ dan $B_{k}$, fungsi $y(t)$ yang didefinisikan sebagai berikut:

$$
y(t)=C_{0} e^{-\frac{1}{\delta} t}+C_{1} e^{r_{0} t}+C_{2} e^{r_{1} t}+C_{3} e^{r t}+\sum_{k=1}^{\infty} e^{p_{k} t}\left(C_{1 k} \cos \left(q_{k} t\right)+C_{2 k} \sin \left(q_{k} t\right)\right)
$$


merupakan solusi dari persamaan diferensial tunda (1.2), dimana

(1) $C_{0}=C_{1}=C_{2}=C_{3}=0$ untuk $\alpha<-\frac{1}{\delta e}$,

(2) $C_{1}=C_{2}=C_{3}=0$ dan $C_{0}$ adalah sebarang, untuk $\alpha=-\frac{1}{\delta e}$,

(3) $C_{0}=C_{3}=0$ dan $C_{1}, C_{2}$ adalah sebarang dan $r_{0}, r_{1}$ merupakan akar riil pada persamaan (2.2) untuk $-\frac{1}{\delta e}<\alpha<0$,

(4) $C_{0}=C_{1}=C_{2}=0$ dan $C_{3}$ adalah sebarang, dengan $r$ merupakan akar riil pada persamaan (2.2) untuk $\alpha>0$.

\section{Kesimpulan}

Solusi persamaan diferensial tunda

$$
\begin{aligned}
y^{\prime}(t) & =\alpha y(t-\delta), \text { pada }[0, b], b>0 \\
y(t) & =\phi(t), \text { pada }[-\delta, 0],
\end{aligned}
$$

adalah

$$
y(t)=C_{0} e^{-\frac{1}{\delta} t}+C_{1} e^{r_{0} t}+C_{2} e^{r_{1} t}+C_{3} e^{r t}+\sum_{k=1}^{\infty} e^{p_{k} t}\left(C_{1 k} \cos \left(q_{k} t\right)+C_{2 k} \sin \left(q_{k} t\right)\right),
$$

dimana

(1) $C_{0}=C_{1}=C_{2}=C_{3}=0$ untuk $\alpha<-\frac{1}{\delta e}$,

(2) $C_{1}=C_{2}=C_{3}=0$ dan $C_{0}$ adalah sebarang, untuk $\alpha=-\frac{1}{\delta e}$,

(3) $C_{0}=C_{3}=0$ dan $C_{1}, C_{2}$ adalah sebarang dan $r_{0}, r_{1}$ merupakan akar riil pada persamaan (2.2) untuk $-\frac{1}{\delta e}<\alpha<0$,

(4) $C_{0}=C_{1}=C_{2}=0$ dan $C_{3}$ adalah sebarang, dengan $r$ merupakan akar riil pada persamaan (2.2) untuk $\alpha>0$.

\section{Daftar Pustaka}

[1] Boyce, W. E dan DiPrima, R.C. 1992. Elementary Differential Equations and Boundary Value Problems. McGraw-Hill Book Co, Singapore

[2] Churchill, R V dan Brown, C W. 1996. Complex Variables and Applications. McGraw-Hill Book Co, Singapore

[3] Debnath, Lokenath. 2012. Nonliear Partial Differential Equations. Springer, New York

[4] Falbo, C. E. 2009. Analytic and Numerical Solution to The Delay Differential Equation $y^{\prime} t=\alpha y(t-\delta)$ Revised.

[5] Falbo, C. E. 2006. Some Elementary Methods for Solving Functional Differential Equations.

[6] Hale, J., dan Lunel, S. M. V. 1993. Introduction to Functional Diferential Equations. Springer-Verlag, New York

[7] Spiegel, M R. 1987. Seri Buku Schaum Teori dan Soal-Soal Peubah Kompleks. Erlangga, Jakarta

[8] Toaha, S. 2008. Model Dengan Tundaan Waktu. Vol. 4, pp 13 - 22 